\title{
Aplikasi Konsep Produksi Ramping untuk Memperbaiki Efisiensi Pengolahan Minyak Kelapa Sawit
}

\author{
Adriansyah $^{1)}$, Agus Sutanto ${ }^{2)^{*}}$, Berry Yuliandra ${ }^{3)}$ \\ ${ }^{1)}$ Program Magister Jurusan Teknik Mesin, Universitas Andalas \\ ${ }^{2,3)}$ Fakultas Teknik Jurusan Teknik Mesin Fakultas Teknik Universitas Andalas \\ Kampus Limau Manis Padang-25163, Indonesia \\ naskah masuk 31/05/2018; diterima 10/10/2018; terbit 29/10/2018 \\ doi: 10.24843/JEM.2018.v11.i02.p01
}

\begin{abstract}
Abstrak
Manfaat dari penelitian ini adalah untuk menerapkan konsep produksi ramping (lean manufacturing) pada proses pengolahan minyak kelapa sawit sehingga pemborosan yang terjadi dapat diidentifikasi serta diminimasi. Identifikasi pemborosan dilakukan melalui pengamatan dan kuesioner. Hasil identifikasi dengan menggunakan kuesioner digunakan sebagai dasar untuk menentukan alat pemetaan VALSAT yang sesuai untuk digunakan dalam analisis. Identifikasi pemborosan dengan kuesioner menunjukkan bahwa stasiun yang banyak menghasilkan pemborosan adalah loading ramp dan sterilizer. Berdasarkan konsep produksi ramping, pemborosan pada pengolahan CPO berdasarkan urutan tertinggi adalah ini adalah aktivitas menunggu, diikuti oleh transportasi dan gerakan berlebih, proses yang tidak diinginkan dan kecacatan bahan baku. Berdasarkan Value Stream Mapping (VSM) kondisi saat ini diketahui bahwa total waktu pengolahan CPO adalah 32700 detik serta efisiensi pengolahan CPO sebesar $30,7 \%$. Kapasitas pengolahan sebesar 40 ton TBS/jam dan operator berjumlah sebanyak 26 operator. Rancangan perbaikan yang diusulkan dapat menurunkan total waktu produksi menjadi 23472 detik sekaligus memperbaiki efisiens pengolahan menjadi 35,6\% dengan kapasitas olah menjadi 55 ton TBS/jam dan dengan pengurangan operator hingga 5 orang.
\end{abstract}

Kata kunci: Produksi ramping, pemborosan, VALSAT, VSM.

\section{Abstract}

The objective of this research is to implement the concept of lean manufacturing in the oil palm fruit processing, so the wastes that commonly occur can be identified and minimized. The identification method of wastes is done through the observations and questionnaires. The result of identification by questionnaires was applied to determine the appropriate VALSAT mapping tool used in analysis. Identification of waste by using questionnaires shows that the wasteful stations are loading ramp and sterilizer. Based on lean concept, the overall wastes occured in CPO processing are waiting with an highest average score,and then followed by excessive transportation and movements, unexpected processing and defects of the raw material. Based on Value Stream Mapping (VSM) of the current condition is known,that the total processing time of CPO is 32700 second with processing efficiency equal to $30,7 \%$. The capacity is 40 tons of fresh fruit bunches per hour with 26 operators. The proposed improvement plan can reduce the total production time up to 23472 seconds while increasing processing efficiency to $35.6 \%$ with capacity to 55 tons of fresh fruit bunches per hour and with operator reduction up to 5 people.

Keywords: Lean manufacturing,wastes, VALSAT, VSM

\section{Pendahuluan}

Pengolahan hasil industri perkebunan kelapa sawit di Indonesia adalah salah satu penghasil pendapatan nasional dan devisa negara [1]. Perkembangan tanaman kelapa sawit merupakan yang paling pesat dari komoditas lainnya [2]. Meningkatnya luas kebun tersebut terus berkesinambungan terhadap kebutuhan CPO Indonesia. Pengolahan CPO dari kelapa sawit biasanya dilakukan pada beberapa stasiun kerja saling berkaitan dan ketergantungan [3]. Hambatan yang terjadi pada stasiun kerja awal akan mempengaruhi jadwal pelaksanaan pada stasiun kerja selanjutnya. Hal tersebut dapat menyebabkan terjadinya pemborosan jam kerja, jumlah pengolahan di bawah kapasitas olah pabrik, serta pada akhirnya berdampak terhadap peningkatan biaya produksi.

Hasil studi pendahuluan menunjukan bahwa pengolahan CPO tidak terlepas dari adanya pemborosan yang umum ditemui adalah waiting (menunggu) dalam bentuk penumpukan tandan buah sawit (TBS) di stasiun loading ramp sebelum diangkut ke proses selanjutnya. Lamanya waktu penumpukan tersebut berdampak TBS manjadi hampir terlalu matang atau membusuk (defect) sehingga terjadi kehilangan kadar asam lemak bebas dan berkurangnya berat TBS [4].

Salah satu solusi untuk meminimasi pemborosan tersebut adalah dengan menerapkan konsep produksi ramping. Konsep

\footnotetext{
*Korespondensi:

E-mail: sutanto1966@gmail.com
} 
tersebut dapat digunakan dalam mengidentifikasi pemborosan yang ada di sepanjang pengolahan CPO untuk kemudian dianalisis menggunakan Value Stream Mapping (VSM).

Konsep produksi ramping umumnya lebih sering diterapkan pada industri manufaktur yang berproduksi dengan sistem batch production. Penerapan konsep ini dan analisis VSM pada pengolahan CPO belum banyak dijumpai dalam literatur. Akan tetapi beberapa peneliti terdahulu dapat dijadikan sebagai rujukan, seperti Jafri et al yang meneliti peningkatan produksi pada industri warna [5]. Venkataraman et al yang menerapkan konsep produksi ramping di industri otomotif dalam meningkatkan ekspor kapasitas penjualan [6], dan Seyed et al dipenelitiannya mengkaji konsep produksi ramping berdasarkan pendekatan VSM guna meningkatkan hasil produksi serta meminimasi pemborosan [7].

\section{Tinjauan Pustaka}

Secara umum proses pengolahan TBS hingga menjadi CPO terdiri dari beberapa stasiun pengolahan seperti stasiun loading ramp, stasiun sterilizer, stasiun thresher, stasiun screw press, stasiun clarification, (6) stasiun penyimpanan CPO [8]. Identifikasi pemborosan dalam pengolahan CPO dapat dilakukan melalui kombinasi konsep produksi ramping, VALSAT dan VSM.

Konsep produksi ramping merupakan suatu usaha berkelanjutan untuk mengurangi atau bahkan menghilangkan pemborosan serta meningkatkan nilai tambah (value added) produk barang atau jasa serta memberikan nilai kepada pelanggan [9]. Pada intinya konsep tersebut menekankan pada pelaksanaan produksi yang efisien sehingga dapat menekan pengeluaran biaya dan pada akhirnya produsen dapat memperoleh keuntungan dari minimasi biaya tersebut. Secara umum terdapat tujuh jenis pemborosan dalam lingkungan manufaktur [10] yaitu (1) produksi yang berlebih, (2) menunggu, (3) pengangkutan berlebih, (4) proses yang tidak diinginkan, (5) persediaan berlebih, (6) gerakan berlebih, (7) produk cacat. Selain ketujuh pemborosan tersebut, dalam analisis juga dapat ditambahakan jenis pemborosan kedelapan yang sering disebut istilah waste $7+1$, yaitu overall structure. Jenis pemborosan tersebut meliputi desain yang tidak termanfaatkan [9], [11].

Identifikasi pemborosan dapat dilakukan melalui pengamatan langsung maupun penyebaran kuesioner kepada operator yang berhubungan dengan proses produksi. Penelitian ini menggunakan kuesioner sebagai cara untuk mengidentifikasi pemborosan yang ada. Cara tersebut digunakan sehingga analisis dapat dilakukan dengan lebih mudah menggunakan Value Stream Analysis Tool (VALSAT). Dari bobot hasil kuesioner identifikasi pemborosan dapat dikalikan berdasarkan matrix skala VALSAT [12]. Melalui skala VALSAT ini dampak yang ditimbulkan oleh pemborosan dapat dianalisis secara lebih mendalam [13]. VALSAT terdiri dari tujuh alat pemetaan [13],[14]: (1) Process Activity Mapping (Pemetaan Aktivias Proses) (2) Supply Chain Response Matrix (Matrik Rerespon Rantai Pasok) (3) Production Variety Funnel (Corong Variasi Produksi) (4) Quality Filter Mapping (Pemetaan Filter Kualitas) (5) Demand Amplification Mapping (Pemetaan Amplifikasi Permintaan) (6) Decision Point Analysis (AnalisisTitik Keputusan) (7) Physical Structure (Struktur Fisik).

Ketujuh alat tersebut digunakan untuk menghasilkan VSM. Value Stream Mapping diartikan sebagai pemetaan semua aktivitas baik itu aktivitas bernilai tambah, tidak mempunyai nilai tambah dan aktivitas tidak bernilai tambah tapi diperlukan untuk memproduksi produk [15]. Hasil yang diperoleh dari penerapan VSM ini adalah visualisasi keseluruhan proses manufaktur, yang nantinya akan dapat digunakan untuk mendeteksi hasil pemborosan, menunjukkan hubungan antara aliran material dan informasi, serta dapat mempermudah bagi peneliti ataupun operator untuk memahami aliran proses manufaktur [9].

\section{Metodologi Penelitian}

Metodologi dalam penelitian ini bersifat kualitatif deskriptif, dimana penyelidikan mengenai gambaran kondisi pabrik dilakukan melalui wawancara secara lisan maupun tulisan dari operator pabrik yang dianggap telah berpengalaman dan benar-benar memahami pengolahan CPO. Penelitian dilakukan dengan langkah-langkah diantaranya: (1) Pengamatan aktivitas pengolahan $\mathrm{CPO}$, yang dilakukan secara langsung serta melibatkan diskusi dan wawancara terhadap operator yang terlibat dilapangan. Pengamatan dilakukan pada keseluruhan proses pada enam stasiun kerja proses pengolahan kelapa sawit, (2) Penghitungan waktu proses rata-rata pada setiap stasiun kerja dengan diukur oleh alat stopwatch sebanyak tiga sampel yaitu pagi hari pukul 08.00 WIB, siang dilakukan pada pukul 14.00 WIB dan terakhir sore hari pada pukul 17.00 WIB; (3) Mengidentifikasi pemborosan yang dilakukan melalui tiga tahap: Pengamatan secara langsung oleh peneliti juga dilakukan pengisian formulir indentifikasi pemborosan, pengisian kuesioner oleh tiga orang responden dan menentukan korelasi jenis pemborosan yang berhasil diidentifikasi dengan alat pemetaan VALSAT yang sesuai; serta (4) Pembuatan VSM yang dilengkapi dengan informasi total waktu siklus yang tergolong dalam kategori kegiatan yang tidak bernilai tambah atau non value added (NVA), kegiatan yang diperlukan dan tidak 
bernilai tambah atau necessary non value added (NNVA) dan kegiatan bernilai tambah atau value added (VA) serta lead time keseluruhan proses produksi.

\section{Hasil dan Pembahasan}

Hasil identifikasi menggunakan formulir identifikasi pemborosan menunjukkan jenis pemborosan yang banyak terjadi dengan urutan sebagai berikut: (1) waiting memiliki nilai rata-rata 4,39. (2) unnecessary transportation bernilai 3,5. (3) unnecessary motion memiliki score 2,78. (4) inappropriate processing dengan nilai 2,72. (5) Defects bernilai 2,67 (6) Overproduction dengan score 2,28. (7) unnecessary inventory 1,72. (8) waste $7+1$ overal structure bernilai 1,39 . Penilaian dilakukan oleh tiga orang responden dengan skala penilaian $1-7$. Stasiun kerja yang banyak menghasilkan pemborosan terdapat pada loading ramp dan sterilizer. Hal ini karena pengolahan di dua stasiun dioperasionalkan secara manual oleh operator atau bersifat tidak berkesinambungan.

Korelasi hasil identifikasi pemborosan dengan VALSAT menunjukkan peringkat sebagai berikut : (1)Process Activity Mapping berbobot 150,25. (2) Supply Chain Response Matrix dengan nilai 66, (3) Demand Amplification berbobot 48. (4) Decision Point Analisis bernilai 34,24. (5) Quality Filter Mapping bobot 30,42. (6) Production Variety Funnel nilai 21,88. (7) Physical Structure Mappingdengan bernilai 17,73. Berdasarkan hasil tersebut, analisis pemborosan hanya akan dilakukan dengan menggunakan alat pemetaan yang memiliki peringkat bobot tertinggi, yaitu Process Activity Mapping dengan bobot 150,25.

\subsection{PAM Kondisi Saat Ini}

Hasil Process Activity Mapping (PAM) untuk kondisi saat ini menunjukkan bahwa terdapat 18 jenis aktivitas seperti ditunjukkan pada Tabel 1. Rinciannya adalah empat jenis aktivitas operation, empat jenis aktivitas inspection, enam jenis aktivitas transport, jenis storage tidak ada aktivitas dan empat jenis aktivitas delay. Total seluruh waktu proses adalah 32700 detik atau setara dengan 545 menit atau 9,08 jam. Ratarata untuk masing-masing stasiun adalah 1,51 jam menghasilkan 60 ton TBS serta operator berjumlah 26 orang. Hal ini berarti kapasitas olah produksi CPO PT XYZ kondisi saat ini berkapasitas olah sebesar 40 ton TBS per jam.

\subsection{VSM Kondisi Saat Ini}

VSM untuk kondisi pengolahan CPO dapat dilihat selengkapnya pada Gambar 1. total waktu keseluruhan proses selama 32.700 detik. Total waktu terdiri dari kegiatan VA selama 10.040 detik, kegiatan NVA selama 4.560 detik dan NNVA selama 18.100 detikdengan total operator 26 orang. Kemudian efisiensi pengolahan CPO (perbandingan kegiatan VA terhadap total lead time) mencapai 30,7\%.

Tabel 1. Process Activity Mapping (PAM) Saat Ini

\begin{tabular}{|c|c|c|c|c|c|c|c|c|c|c|c|c|}
\hline \multirow{2}{*}{ No } & \multirow{2}{*}{ Stasiun } & \multirow{2}{*}{ Aktivitas } & \multirow{2}{*}{ Mesin/area } & \multirow{2}{*}{$\begin{array}{c}\text { Jarak } \\
(\mathrm{m})\end{array}$} & \multirow{2}{*}{$\frac{\text { Waktu }}{\text { (s) }}$} & \multirow{2}{*}{$\frac{\text { Jumlah }}{\text { Operator }}$} & \multicolumn{5}{|c|}{ Jenis Aktivitas } & \multirow{2}{*}{$\begin{array}{l}\text { VA/ } \\
\text { NVA } \\
\text { INNVA }\end{array}$} \\
\hline & & & & & & & o & 1 & $\mathbf{T}$ & $s$ & D & \\
\hline \multirow{5}{*}{1} & \multirow{5}{*}{$\begin{array}{l}\text { Loading } \\
\text { ramp }\end{array}$} & 1. Melakukan penimbangan buah sawit & Timbang & 10 & 1680 & 1 & & $\mathrm{X}$ & & & & NNVA \\
\hline & & 2. Melakukan kegiatan pembongkaran buah sawit & Loading ramp & 250 & 3000 & 2 & & $\mathrm{X}$ & & & & NNVA \\
\hline & & 3. Menyortir buah sawit dari petani & Loading ramp & 5 & 2280 & 5 & & $\mathrm{X}$ & & & & NNVA \\
\hline & & 4. Memeriksa kembali kualitas buah sawit (QC) & Loading ramp & 5 & 2100 & 4 & & & & & $\mathrm{X}$ & NVA \\
\hline & & 5. Mengontrol buah sawit sangkut & Conveyor & 18 & 540 & 2 & & & & & $\mathrm{X}$ & NVA \\
\hline \multirow{5}{*}{2} & \multirow{5}{*}{ Sterilizer } & 1. Mengangkut buah sawit dengan conveyor chain & Conveyor & 200 & 1080 & 0 & & & $\mathrm{X}$ & & & NNVA \\
\hline & & 2. Menumpuk sementara buah sawit & Sterilizer & 5 & 1020 & 1 & & & & & $\mathrm{X}$ & NVA \\
\hline & & 3. Melakukan aktivitas perebusan buah sawit & Sterilizer & 5 & 4200 & 2 & $\mathrm{X}$ & & & & & VA \\
\hline & & 4. Memilih buah yang belum sempurna direbus & Conveyor & 3 & 900 & 2 & & & & & $\mathrm{X}$ & NVA \\
\hline & & 5. Mengumpankan buah sawit ke conveyor & Conveyor & 10 & 480 & 0 & & & $\mathrm{X}$ & & & NNVA \\
\hline \multirow{4}{*}{3} & \multirow{4}{*}{ Thresher } & 1. Mengangkut buah ke area pemisah brondol & Thresher & 100 & 1320 & 0 & & & $\mathrm{X}$ & & & NNVA \\
\hline & & 2. Memisah brondol terhadap janjangan buah sawit & Thresher & 7 & 800 & 0 & $\mathrm{X}$ & & & & & VA \\
\hline & & $\begin{array}{l}\text { 3. Memeriksa janjangan sawit yang belum sempurna } \\
\text { terpisah }\end{array}$ & Bunch press & 15 & 1000 & 2 & & $\mathrm{X}$ & & & & NNVA \\
\hline & & 4. Mengangkut ke bagian screw press & Conveyor & 9 & 900 & 0 & & & $\mathrm{X}$ & & & NNVA \\
\hline \multirow{2}{*}{4} & \multirow{2}{*}{$\begin{array}{l}\text { Screw } \\
\text { press }\end{array}$} & 1. Mengumpankan biji sawit & Screw press & 10 & 2580 & 1 & & & $\mathrm{X}$ & & & NNVA \\
\hline & & 2. Melakukan proses press pada biji brondol & Screw press & 8 & 1320 & 1 & $\mathrm{X}$ & & & & & VA \\
\hline 5 & Clarifier & 1. Memisahkan minyak dari kotoran buah sawit & Clarification & 15 & 3720 & 2 & $\mathrm{X}$ & & & & & VA \\
\hline 6 & $\begin{array}{c}\text { Penyim- } \\
\text { panan }\end{array}$ & 1. Mengisi CPO ke storage tank & Storage Tank & 50 & 3780 & 1 & & & $\mathrm{X}$ & & & NNVA \\
\hline & & TOTAL LEAD TIME PROCESS CPO : & & & $\underline{32700}$ & $\underline{26}$ & & & & & & \\
\hline
\end{tabular}




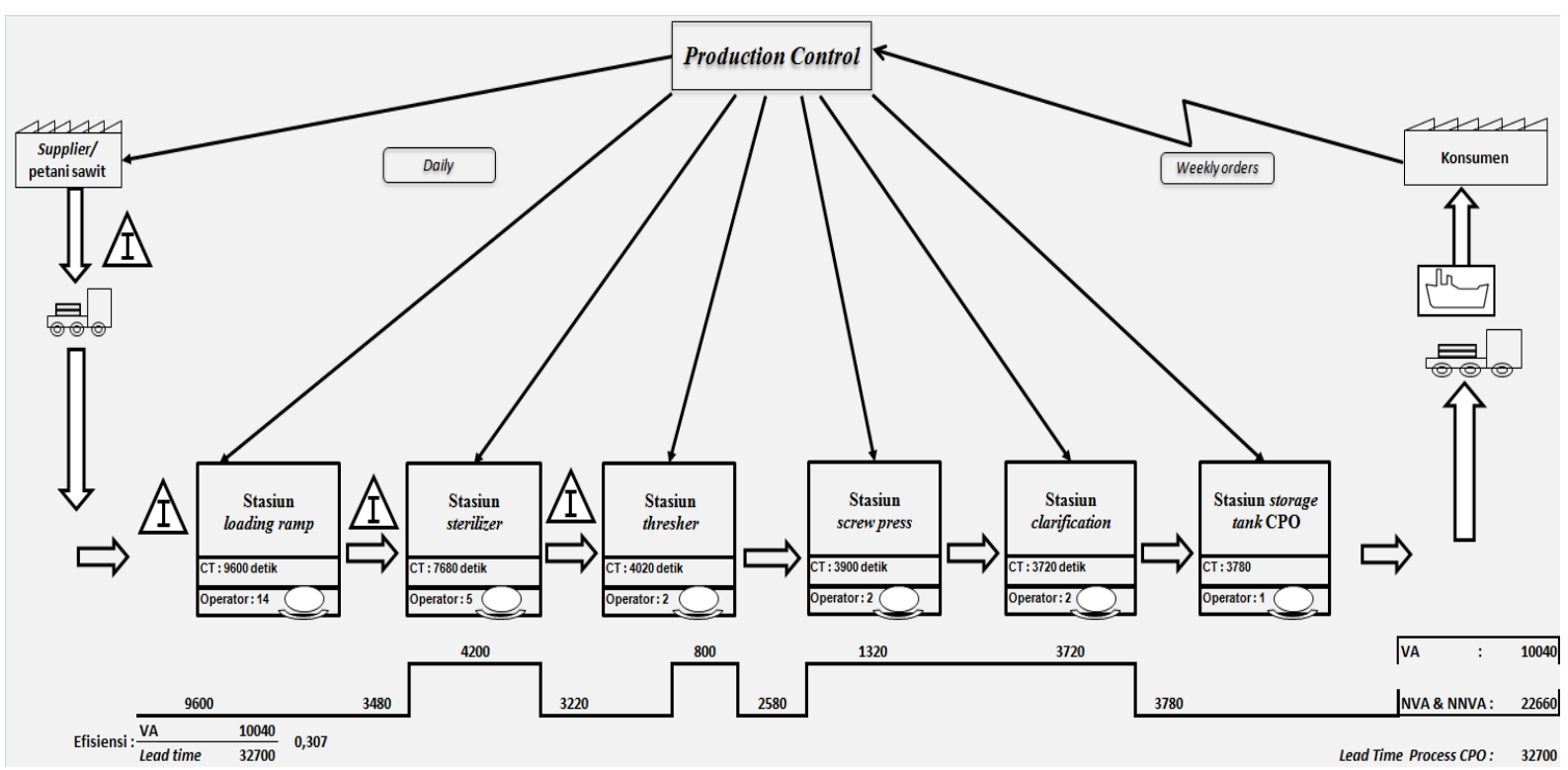

Gambar 1. VSM saat ini

\subsection{Rancangan Perbaikan}

Rancangan perbaikan untuk menghilangkan atau mengurangi pemborosan ini disusun berdasarkan masukan dari hasil diskusi dengan operator pabrik. Perbaikan hanya dilakukan pada stasiun loading ramp dan sterilizer, sebagai dua stasiun kerja yang memiliki jumlah pemborosan terbesar. Perbaikan tersebut adalah aktivitas pertama dan ke-empat pada stasiun loading rampdan aktivitas ke-empat pada stasiun sterilizer (lihat Tabel 1). Hasil rancangan perbaikan kemudian diujikan pada stasiun pengolahan.

Hasil pengujian pada stasiun loading ramp menunjukkan bahwa total waktu aktivitas yang semula selama 9600 detik, dapat dikurangi menjadi 3900 detik dengan jumlah operator 10 orang (berkurang 4 operator dari semula). Pada stasiun area sterilizer, total jumlah waktu proses semula 7680 detik dapat dikurangi menjadi 4152 detik. Operator yang semula berjumlah lima orang dapat dikurangi menjadi empat orang.

\subsection{Rancangan PAM}

Hasil PAM bagi rancangan yang perbaikan menunjukkan bahwa aktivitas pengolahan CPO dapat dikurangi menjadi 17 jenis aktivitas (berkurang satu aktivitas dari kondisi semula). Satu aktivitas yang dieliminasi adalah aktivitas memilih kembali TBS oleh bagian QC. Total waktu proses rancangan perbaikan berkurang menjadi 23472 detik atau 391 menit. Jumlah operator yang diperlukan berkurang menjadi 21 operator. Rata-rata waktu proses untuk masingmasing stasiun kerja adalah 1,08 jam, yang berarti kapasitas olah pabrik pada rancangan perbaikan meningkat menjadi 55 ton
TBS/jam.Peningkatan kapasitas ini terjadi karena pengurangan waktu operasi pada stasiun loading ramp dan sterilizer. Hal ini dapat dicapai dengan cara meningkatkan kapasitas perebusan sterilizer dari 40 ton/jam (kondisi sekarang) menjadi 60 ton/jam. Dengan peningkatan kapasitas ini, waktu tunggu di stasiun sterilizer dapat dikurangi untuk masing-masing aktivitas di stasiun sterilizer. Secara keseluruhan waktu total pada sterilizer dapat direduksi dari 7680 detik menjadi 4152 detik.

\subsection{Rancangan VSM yang Akan Datang}

VSM untuk rancangan perbaikan dapat dilihat selengkapnya pada Gambar 2. Waktu proses stasiun loading ramp pada rancangan perbaikan hanya memerlukan 3900 detik dengan jumlah operator 10 orang. Untuk stasiun area sterilizer diketahui waktu pengolahan selama 4152 detik dengan jumlah operator 4 orang. Stasiun berikutnya seperti stasiun thresher, screw press, clarification dan stasiun storage tank tidak begitu ada perubahan, hal ini karena pemborosan yang terjadi tidak terlalu signifikan. Hasil akhir waktu yang dihabiskan selama pengolahan CPO pada rancangan perbaikan adalah 23.472 detik meliputi kegiatan aktivitas bernilai tambah (VA) selama 8360 detik, kegiatan yang tidak memberi nilai tambah (NVA) selama 1236 detik dan kegiatan yang tidak memberi nilai tambah tapi diperlukan (NNVA) selama 13876 detik serta memerlukan sebanyak 21 orang operator dengan efisiensi pengolahan CPO mencapai $35,6 \%$. 


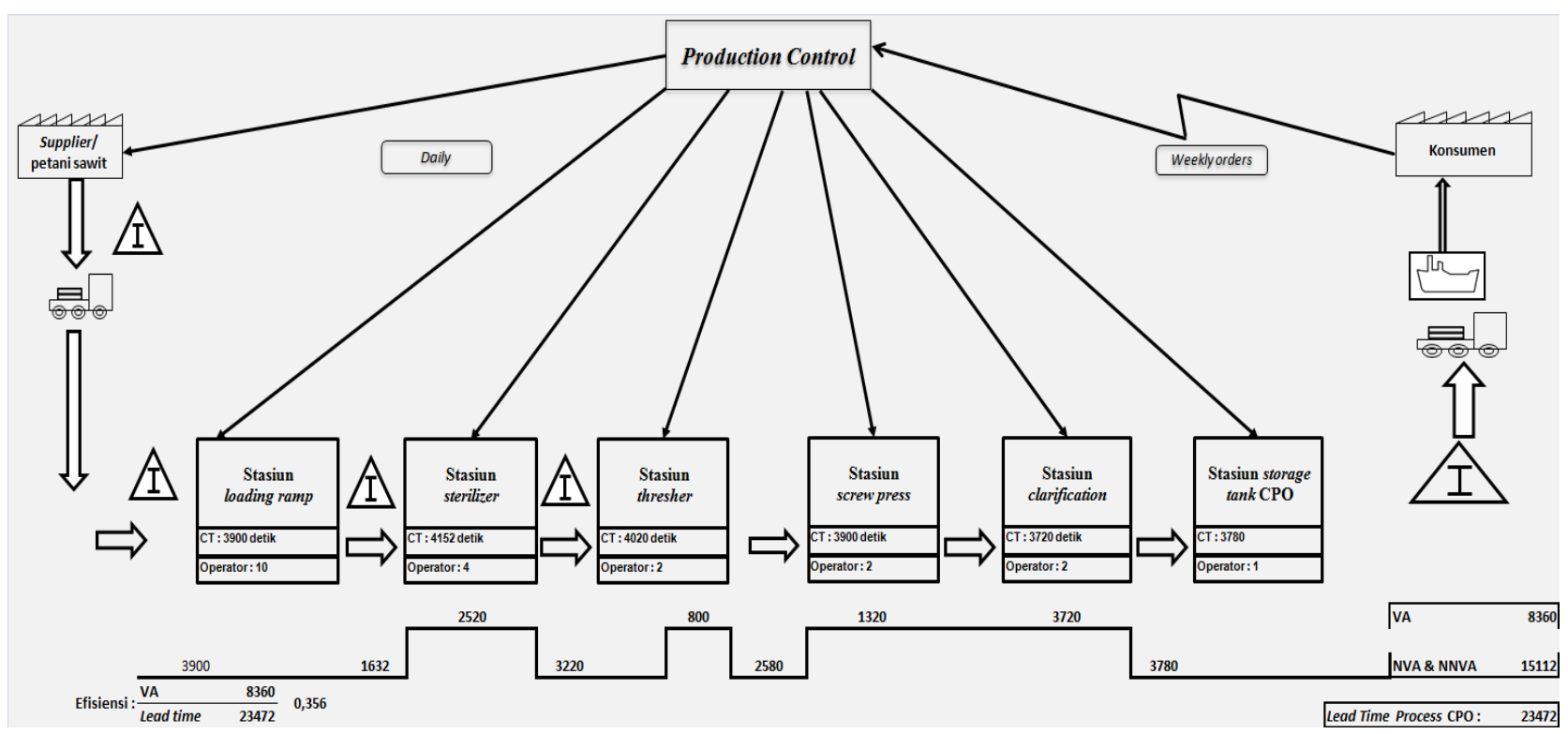

Gambar 2. VSM yang akan datang

\section{Simpulan}

Hasil identifikasi pemborosan pada pengolahan CPO dengan tiga peringkat tertinggi yaitu: (1) menunggu dengan nilai rata-rata 4,39; (2) transportasi berlebihan (unnecessary transportations) sebesar 3,5; dan (3) gerakan berlebihan (unnecessary motions) mempunyai skor 2,78. Lokasi pemborosan dominan terdapat pada stasiun loading ramp dan stasiun sterilizer. Melalui VSM diketahui, bahwa total waktu (lead time) pengolahan CPO pada saat ini 32700 detik dengan kapasitas olah 40 ton TBS/jamserta dioperasikan oleh 26 operator. Efisiensi pengolahan CPO yang merupakan perbandingan waktu proses yang bernilai tambah dengan waktu total keseluruhan proses sebesar $30,7 \%$. Selanjutnya dengan menggunakan metode VALSAT melalui tool PAM, telah dirancang VSM kondisi akan datang yang dapat mengelimasinasi satu aktivitas di stasiun loading ramp dan mereduksi beberapa aktivitas yang tidak bernilai tambah pada stasiun sterilizer sehingga total waktu pengolahan yang baru menjadi 23472 detik serta kapasitas olah meningkat menjadi 55 ton TBS/jam dengan 5 operator lebih sedikit dari kondisi saat ini. Efisiensi pengolahan CPO meningkat menjadi $35,6 \%$.

\section{Daftar Pustaka}

[1] Direktorat Jendral Perkebunan Indonesia., Statistik Perkebunan Indonesia Komoditas Kelapa Sawit, Jakarta, 2016.

[2] Subriyanto.,Pemilihan Teknologi Sterilizer Pada Pabrik Kelapa Sawit Menggunakan
Metode Analytical Hierarchy Process, Jurnal Teknik Industri, 2013.

_.,Proses Pengolahan PKS, [http://indrarexs.blogspot.co.id/2013/06/pros es-pengolahan.html.](diakses Januari 2017)

[4] Subekti, P.,Analisa Kerusakan Short Drive Shaft Kempa Ulir Pada Pabrik Kelapa Sawit, Jurnal APTEK Vol. 3 No. 1 Januari2010.

[5] Jafri, M.R., Production Line Analysis Via Value Stream Mapping:A Lean Manufacturing Process of Color Industry,Procedia Manufacturing Vol.2 2015.

[6] Venkataraman, K., Application of Value Stream Mapping ForReduction Of Cycle Time In a Machining Process, Procedia Material Science, 2014.

[7] Seyed, M.Z.,Lean Manufacturing Implementation Through Value Stream Mapping: A Case Study, Jurnal Teknologi Science \& Engineering, 2004.

[8] Virgilio,P.,Sustainbility of Palm Oil Production and Opportinities For Finnish Technology and Know-How Transfer, Lappeenranta University of Technologi, Faculty of Technologi, Lappeenranta, Finland, 2009.

[9] Vincent, G.,Lean Six Sigma For Manufacturing and Service Industries, Gramedia pustaka utama Jakarta, 2007.

[10] Peter, H\& David, T.,Going lean, Cardift UK,Lean Enterprise Research Centre, 2000. 
[11] Dwiyani. W.,Alur Proses Pelayanan Unit Rawat Jalan Dengan Mengaplikasikan Lean Hospital di RS Marinir Cilandak, Tesis, Universitas Indonesia, Jakarta, 2012.

[12] Ayunda. N.,Pendekatan Metode Lean Guna Mengidentifikasi Waste (pemborosan) Dengan Menggunakan Value Stream Analysis Tools (VALSAT) Serta Usulan Perbaikan Pada Proses Produksi Pot Krim 12,5gr, Universitas Airlangga, Surabaya, 2012.

[13] Taufik.K.,Perancangan Lean Manufacturing Dengan Metode Valsat Pada Line Produksi Drum Brake Type, FT Universitas Indonesia, Jakarta, 2012.

[14] Peter. H and Nich. R., The Seven Value Stream Mapping Tools, Vol.17, 1997.

[15] Mike. R and John. S., Learning To See Value Stream Mapping to Create Value and Eliminate Muda, Brookline Massachusetts, USA,1999.

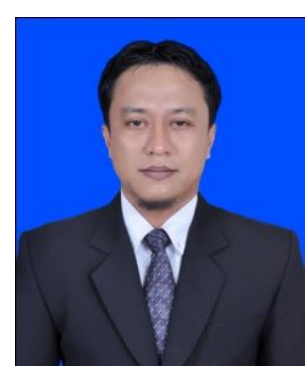

Adriansyah, Lulusan S1 Teknik Mesin Institut Teknologi Padang tahun 2005.Sejak tahun 2015, terdaftar sebagai mahasiswa Magister (S2) Teknik Mesin Universitas Andalas dan sekaligus bekerja sebagai dosen di Jurusan Teknik Mesin Sekolah Tinggi Teknologi Indragiri. Penulis meminati penelitian yang berkaitan dengan sistem manufaktur, terutama topik yang terkait dengan lean manufacturing. 